\title{
Cutting Power during Milling of Thermally Modified Pine Wood
}

\section{Snaga rezanja pri glodanju toplinski modificiranog drva}

\author{
Original scientific paper • Izvorni znanstveni rad \\ Received-prispjelo: 18. 6. 2015. \\ Accepted-prihvaćeno: 5. 5. 2016. \\ UDK: $630 * 823.121 ; 630 * 847.2 ; 674.031 .475 .442$ \\ doi:10.5552/drind.2016.1527
}

\begin{abstract}
The paper presents experimental testing results of cutting power of thermally modified wood of Scots pine (Pinus sylvestris L.) during lengthwise milling. The process of heat treatment was performed in the atmosphere of superheated steam, at temperatures of 130, 160, 190 and $220^{\circ} \mathrm{C}$, maintaining an identical heating time of $4 \mathrm{~h}$ for all modification variants. Cutting power was determined during milling of the radial surface of modified and non-modified samples. It was calculated as the difference of power used by a milling machine during wood machining and at idling. Based on the results of measurements, it was found that, in the case of modified wood, cutting power decreases with an increase in modification temperature (the dependence being linear) and increases with an increase in the working engagement. At temperatures exceeding $160^{\circ} \mathrm{C}$, the power required for milling of modified wood is lower than cutting power for non-modified wood. The experiment indicated a significant reduction of cutting power with an increase in wood modification temperature. It was also found that an increase in the working engagement results in an increase of cutting power both in thermally modified and non-modified wood.
\end{abstract}

Key words: woodworking, thermal modification, cutting, lengthwise milling, power consumption, softwood, Pinus sylvestris $L$.

SAŽETAK • U radu su prikazani rezultati eksperimentalnih istraživanja snage rezanja toplinski modificiranog drva običnog bora (Pinus sylvestris L.) tijekom njegove obrade glodanjem. Proces toplinske obrade borovine proveden je u atmosferi pregrijane pare, pri temperaturi od 130, 160, 190 i $220^{\circ} \mathrm{C}$, uz jednako vrijeme grijanja od četiri sata za sve varijante modifikacije. Snaga rezanja određena je pri glodanju radijalne površine modificiranih i nemodificiranih uzoraka, a izračunana je kao razlika snage izmjerene tijekom rada stroja pri glodanju uzoraka i tijekom praznog hoda stroja.

Na temelju rezultata mjerenja utvrđeno je da se snaga rezanja pri obradi modificiranog drva smanjuje s porastom temperature modifikacije (ovisnost je linearna), a povećava se s povećanjem visine dodatka za obradu (visine glodanja). Snaga potrebna za glodanje drva modificiranoga na temperaturama višim od $160{ }^{\circ} \mathrm{C}$ manja je od snage rezanja za obradu nemodificiranog drva. Eksperiment je pokazao znatno smanjenje snage rezanja s povećanjem temperature modifikacije drva. Također je utvrđeno da je povećanje visine dodatka za obradu rezultiralo povećanjem snage rezanja, kako pri obradi toplinski modificiranoga, tako i pri obradi nemodificiranog drva.

Ključne riječi: obrada drva, toplinska modifikacija, rezanje, protusmjerno glodanje, potrošnja energije, meko drvo, Pinus sylvestris L.

\footnotetext{
${ }^{1}$ Authors are associate professor and assistants at Poznań University of Live Sciences, Faculty of Wood Technology, Department of Woodworking Machinery and Basis of Machines Construction, Poznań, Poland.

Autori su izvanredni profesor i asistenti Sveučilišta bioloških znanosti u Poznanju, Fakultet drvne tehnologije, Odjel za strojeve za obradu drva i elemente strojeva, Poznanj, Poljska.
} 


\section{INTRODUCTION}

\section{UVOD}

Wood subjected to thermal treatment has been increasingly used in Europe and worldwide. One of the many types of thermal modification of wood is ThermoWood $\AA$ technology. Due to many advantageous properties of ThermoWood, its production is increasing, at present accounting for the greatest share in the total production of thermally modified wood in Europe, while most frequently modified softwood species are pine and spruce (Ala-Viikari, 2007; Boonstra et al., 2007).

During the thermal modification process, many significant changes take place in the chemical structure of wood, affecting its properties. High-temperature treatment causes degradation of chemical cell wall components (cellulose, hemicellulose, lignins). Heating of wood initially reduces its weight as a result of losses of free and hygroscopic water and release of volatile minor components. A further increase in temperature results in changes in the structure of polymer cell wall components, mainly carbohydrates (Hill, 2006; Doczekalska, 2010). The basic structural components of wood are degraded, while cellulose and lignin are broken down at a slower rate and at higher temperatures than hemicelluloses. Moreover, extractives are also degraded and they are released during the modification process (Hill, 2006; Borysiuk and Mamiński, 2007; Doczekalska, 2010). Thermal modification of wood results in reduced contents of low-polymer carbohydrates components, depolymerisation of cellulose and a reduction of its crystallinity. Positive effects of these changes include e.g. reduced hygroscopicity and changes in wood colour to darker, resembling that of exotic species (Nakao et al., 1983; Fangel and Wegener, 1984; Jämsä et al., 2000; ThermoWood® Handbook, 2003). Reduced wood density in thermal treatment is caused by the degradation of its components, mainly hemicellulose, to volatile substances, released during wood modification (Bekhta and Niemz, 2003; Pétrissans et al., 2003).

Thermally modified wood, in comparison to non-modified wood, is characterised by greater natural durability - resistance to biotic and abiotic factors, enhanced dimensional stability and hardness. For this reason, it is used as a suitable material for the production of floors, stairs, ceilings, paneling, elements of building facades, while it is also successfully used in humid facilities such as saunas and bathrooms (Borysiuk and Mamiński, 2007). Thermal modification also causes an increase in Young's modulus, brittleness and susceptibility to cracking (González-Peña and Hale, 2007; Boonstra, 2008; Orłowski and Wierzbowski, 2010), as well as reduced specific cutting resistance and specific work of fracture (Orłowski and Grześkiewicz, 2009; Orłowski and Wierzbowski, 2010), tensile strength and bending strength. Changes of mechanical properties of thermally modified wood, especially impact strength. depend on the parameters of the modification process (Barcík and Gašparík, 2014). The effect of thermal treatment of wood is also reflected in differences in particle size of splinter produced during the cutting process. Thermally modified sawdust is finer and dimensionally less homogeneous than native wood (Dzurenda et al. 2010; Dzurenda and Orłowski, 2011; Barcík and Gašparík, 2014).

In technological processes of mechanical conversion, thermally modified wood is subjected to identical cutting operations, e.g. sawing, planing, milling and sanding as non-modified wood. However, in contrast to the physico-mechanical and chemical properties extensively described in literature on the subject, there is a marked shortage of experimental data concerning technological properties of thermally modified wood. Apart from the general information that this type of wood is subjected to machining similarly as non-modified wood, and that due to its greater cleavability excessive loads imposed by feed mechanisms may not be applied, there is no information e.g. on power consumption at its machining or the effect of machining on the quality of worked wood surface. In view of the reported higher hardness, brittleness, susceptibility to cracking and increased Young's modulus in comparison to non-modified wood, at simultaneously reduced density and tensile, shear yield stresses and bending strength, the question concerning energy consumption in machining of thermally modified wood seems justified.

The aim of this study was to determine cutting power of thermally modified wood of Scots pine (Pinus sylvestris L.) during lengthwise milling. This species is commonly used in the Polish wood industry, also in the production of thermally modified wood. The process of thermal modification was conducted under laboratory conditions with the following treatment parameters: constant modification time of $4 \mathrm{~h}$ and varied temperature $\left(130,160,190,220^{\circ} \mathrm{C}\right)$.

\section{MATERIAL AND METHODS}

2. MATERIJAL I METODE

\subsection{Wood}

2.1. Drvo

Experiments were conducted on sapwood of Scots pine (Pinus sylvestris L.) from the central part of Wielkopolska (Great Poland) region in Poland. The material was collected from the centre plank of $63 \mathrm{~mm}$ in thickness, cut above breast height from the butt end of a tree aged approx. 100 years. Density of the wood used in the tests, determined at an $8 \%$ moisture content, was $530 \mathrm{~kg} \cdot \mathrm{m}^{-3}$, the width of annual rings was 2.3 $\mathrm{mm}$, and the share of late wood was $31.6 \%$.

From the defect-free sapwood zone, characterised by the linear course of annual rings at the radial surface of the plank and the parallel course of fibres in relation to its axis, identified on the tangential plane, tangentially oriented slats were cut at a length of approx. $1000 \mathrm{~mm}$, which were then planed to the transverse dimension of $20 \times 50 \mathrm{~mm}$ and cut into sections of $250 \mathrm{~mm}$ in length. In this way pairs of twin samples were produced.

In the course of the measurements, mean equilibrium moisture content of modified wood samples at 130, 160, 190 and $220^{\circ} \mathrm{C}$ was 5.5, 5.1, 4.5 and $3.5 \%$, 
while mean moisture content of non-modified samples for temperatures of 130 and $160{ }^{\circ} \mathrm{C}$ was $5.0 \%$, and for 190 and $220{ }^{\circ} \mathrm{C}$ it was $4.0 \%$. After thermal modification at 190 and $220^{\circ} \mathrm{C}$, wood density was reduced to 525 and $500 \mathrm{~kg} \cdot \mathrm{m}^{-3}$.

\subsection{Thermal modification of wood}

\subsection{Toplinska modifikacija drva}

In this study, the most frequently used method of wood modification in the atmosphere of superheated steam was applied. Wood modification was performed under laboratory conditions in the facilities consisting of a modification chamber, a steam generator, thermocouples and a set of devices to measure and record modification temperatures.

The modification process was conducted as follows: samples were heated until a temperature of 110 ${ }^{\circ} \mathrm{C}$ was reached over their entire volume and this temperature was maintained for $2 \mathrm{~h}$, until an approx. 1 $\%$ moisture content was obtained. Then, the temperature was increased until a pre-set value $(130,160,190$, $220^{\circ} \mathrm{C}$ ) was reached and it was kept constant for $4 \mathrm{~h}$, i.e. the duration of the heating process. From the moment the temperature of $130{ }^{\circ} \mathrm{C}$ was obtained throughout the sample volume, the modification was run in the atmosphere of superheated steam. After completing wood heating at a constant temperature, the heat generator was switched off and after wood temperature decreased to $130{ }^{\circ} \mathrm{C}$, the steam inflow was shut and the samples were left in the chamber until the temperature of wood dropped to ambient temperature.

During the modification process, thermocouples were used to control the temperature of wood and air in the chamber. Thermocouples measuring wood temperature were placed in the middle of the height and width of the control sample, and air temperature was measured using the thermocouple placed over the set of slats. Temperature was read automatically at every 5 min and the data was recorded in the computer program memory.

The course of the modification process is presented in the form of graphic records of changes in temperature in the function of time based on the modification at a temperature of $220^{\circ} \mathrm{C}$ (Fig. 1).

\subsection{Measurements of cutting power \\ 2.3. Mjerenje snage rezanja}

In order to determine the effect of thermal modification on cutting properties of wood, it was decided to measure cutting power during milling. From the point of view of machining kinematics, milling with router does not differ from rotational planing. Milling and rotational planing, as well as sawing, are the most common methods of wood machining.

Cutting power was determined during lengthwise milling of the radial surface of modified and control samples. In order to maintain comparable experimental conditions, the moisture content of the control samples was adjusted prior to the test to moisture content corresponding to the equilibrium moisture content of modified wood. Milling operations were performed using an NC FLA 16 upper-spindle milling machine by OBRUSN (Fig. 2a, b). Constant machining parameters were as follows: rotational speed of the machine spindle of $18000 \mathrm{~min}^{-1}$, feed speed of $1 \mathrm{~m} \cdot \mathrm{min}^{-1}$, tool diameter of 16 $\mathrm{mm}$. The used tool was an end mill with one cutting knife, with a tool blade of cemented carbide HW (producer: TIGRA GmbH, trade name T02SMG - group of application K01) with a wedge angle of $55^{\circ}$. The rake angle was $20^{\circ}$ and the clearance angle was $15^{\circ}$. The working engagement was a variable parameter (height of the machined layer $a_{e}$ ), i.e. $0.5,1$ and $2 \mathrm{~mm}$. For each of these machining variants, 10 replications were performed. Power was measured using an N13 meter of 3-phase current by LUMEL (Fig. 2c). Data on power consumption was transferred digitally using an RS-485

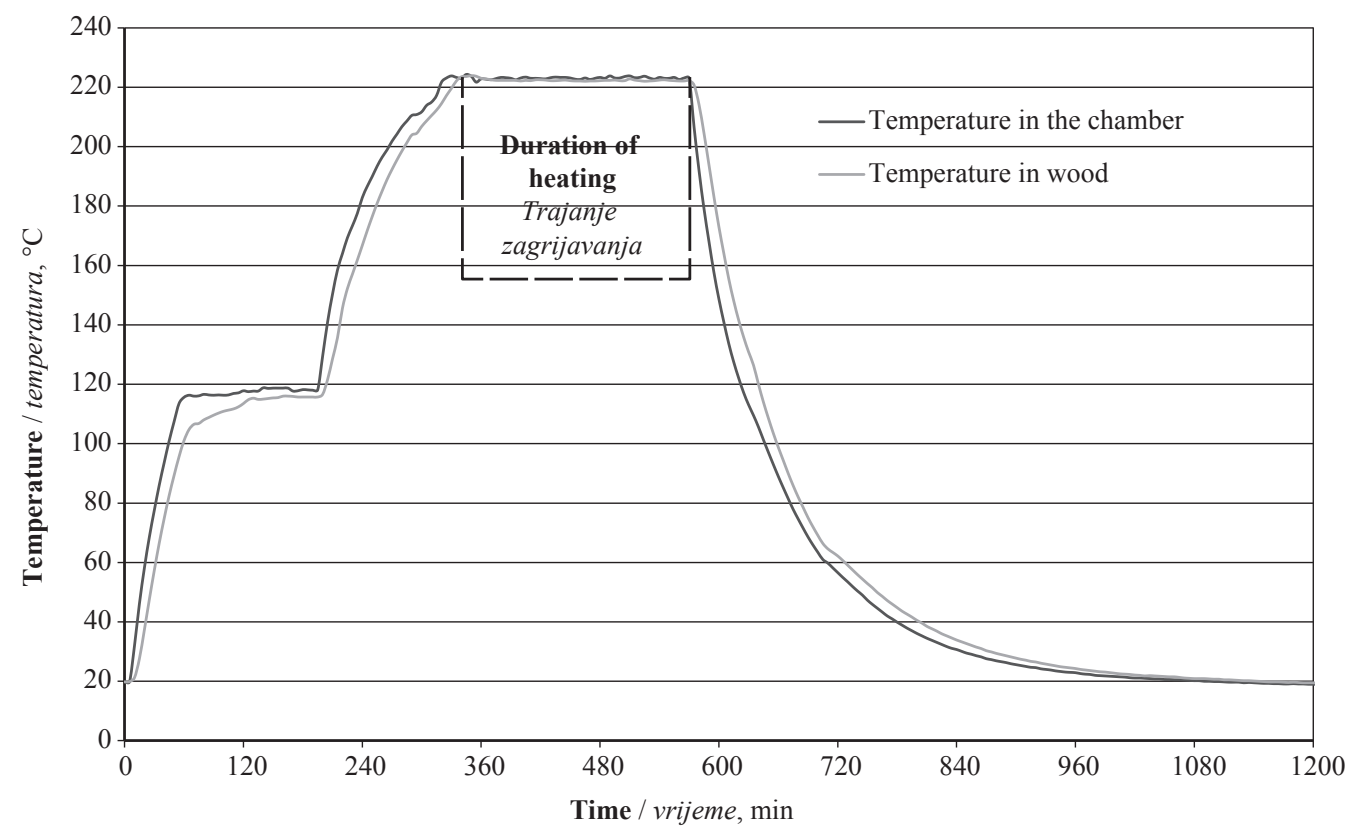

Figure 1 The course of thermal wood modification (temp. $220{ }^{\circ} \mathrm{C}$, time $4 \mathrm{~h}$ )

Slika 1. Tijek toplinske modifikacije drva (temperatura $220^{\circ} \mathrm{C}$, vrijeme $4 \mathrm{~h}$ ) 


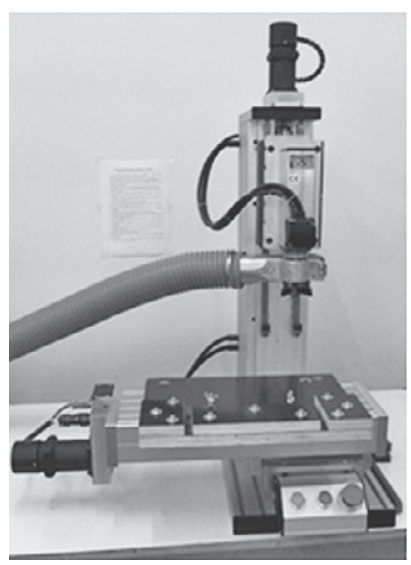

a)

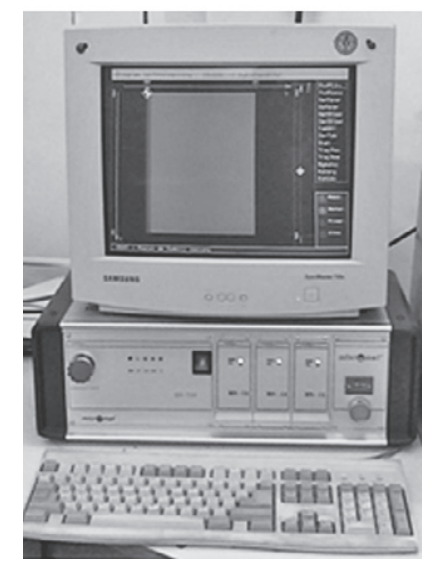

b)

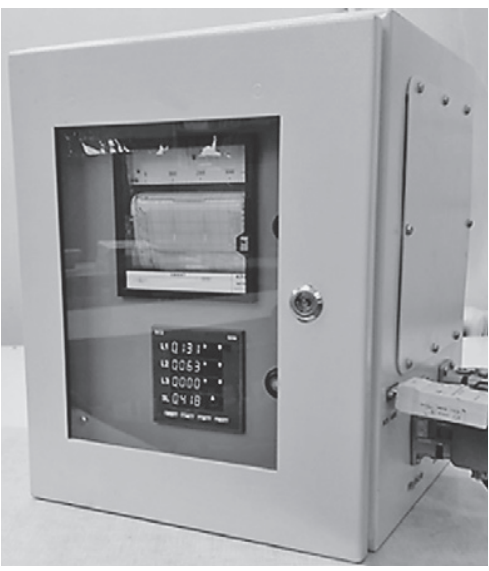

c)

Figure 2 The set of apparatus used to measure cutting power at milling: a) mechanical part of upper-spindle milling machine; b) numerical control of machine; c) meter of 3-phase current

Slika 2. Mjerni lanac upotrijebljen za mjerenje snage rezanja pri glodanju: a) mehanički dio nadstolne glodalice; b) numerička kontrola stroja; c) uređaj za mjerenje električne snage

integrated connector and recorded in the memory of a personal computer. This personal computer was part of a set of apparatus measuring and recording cutting power, which also facilitated visualisation of changes in power in the function of machining time. During the measurements of cutting power, the sampling frequency was 8 Hz. Power demand of the machine tool was determined for the performance of an idling working cycle and the total power used by the machine tool at milling. The cutting power of wood was assumed to be active power consumed during milling, calculated as the difference between total power and idling power.

Figure 3 presents a scheme of plain milling with conventional cutting. The machining operation was performed in the lengthwise-perpendicular system, at the parallel feed direction and the direction of the cutting edge of the blade perpendicular to grain.

\section{RESULTS AND DISCUSSION}

\section{REZULTATI I RASPRAVA}

Numerical data listed in Table 1 are mean values from 10 replications of the milling process of the radial surface of samples. Results were analysed statistically, determining the measure of location - the arithmetic mean $(\bar{x})$, standard error (S.E) and measures of scatter - standard deviation (S.D.) and the coefficient of variation $(v)$. These data show that irrespective of the working engagement and the temperature of wood modification, the coefficients of variation, both for modified and non-modified wood, fell within a narrow range of values from approx. 2 to $7 \%$. Standard error and standard deviation in relation to the mean value of the analysed measure $(\bar{x})$ also assumed low values. Analysis of presented statistical data indicates low variability of results. Mean values of the investigated measure were used in order to illustrate the dependence between the cutting power and the temperature of modification and working engagement.

The graphic presentation of measurements of cutting power in the function of time shows relationships between cutting power of non-modified wood

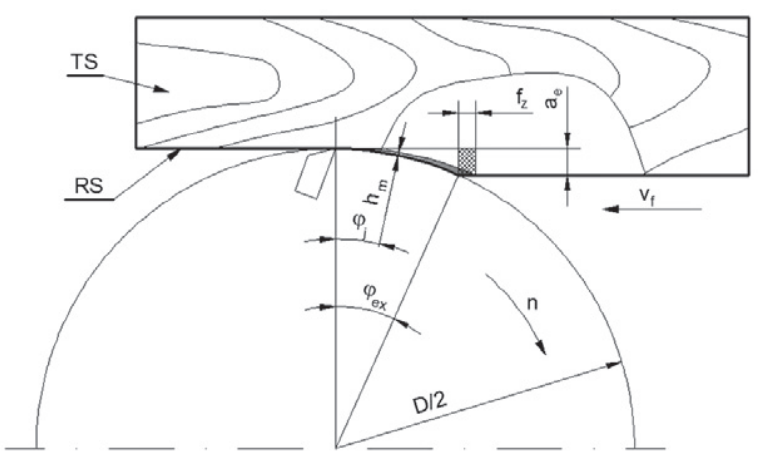

Figure 3 A scheme of plain milling with conventional cutting, where: $D$ - tool diameter, $f_{z}-$ feed per tooth, $a_{e}-$ working engagement, $v_{f}$ - feed speed, $n$ - rotational speed, $h_{m}-$ average uncut chip thickness, $\varphi-$ angular cutting edge position, $R S$ - radial surface, $T S$ - tangential surface

Slika 3. Shema jednostavnoga glodanja konvencionalnim rezanjem: $D$ - promjer alata, $f_{z}$ - posmak po zubu, $a_{e}-$ visina dodatka za obradu, $v_{f}$ - posmična brzina, $n$ - frekvencija vrtnje, $h_{m}$ - srednja debljina strugotine, $\varphi$ - kut zahvata oštrice, $R S$ - radijalna površina, $T S$ - tangencijalna površina

and thermally modified wood for the working engagement of $2 \mathrm{~mm}$ (Figs. 4 and 5).

Cutting power of wood modified at $220{ }^{\circ} \mathrm{C}$ is markedly lower (mean $22 \%$ ) than that of analogous non-modified wood. In contrast, thermal treatment of wood at $130{ }^{\circ} \mathrm{C}$ did not reduce cutting power of modified wood in comparison to non-modified wood.

The dependence of cutting power of thermally modified wood on modification temperature is presented in Fig. 6. An increase in modification temperature causes a decrease in cutting power irrespective of the working engagement. These dependencies within the analysed range of temperatures are well described by linear functions $\left(0.77<R^{2}<0.98\right)$. The reduction of cutting power is proportional to the increase in wood modification temperature and its volume increases with an increase in the working engagement. In the case of a 0.5 -mm layer, its cutting power within the range of modification temperature of $130-220^{\circ} \mathrm{C}$ decreased by 14 $\%$, while for working engagement of 1 and $2 \mathrm{~mm}$, it is more than 2-fold higher, amounting to $30 \%$ and $34 \%$. 
Table 1 Cutting power of thermally modified wood

Tablica 1. Snaga rezanja toplinski modificiranog drva

\begin{tabular}{|c|c|c|c|c|c|c|}
\hline \multirow[t]{4}{*}{$\begin{array}{c}\text { Temperature } \\
\text { Temperatura }{ }^{\circ} \mathrm{C}\end{array}$} & \multicolumn{6}{|c|}{$\begin{array}{c}\text { Cutting power / Snaga rezanja } \\
\bar{x}, \mathrm{~W} \\
\pm \text { S.E., W } \\
\pm \text { S.D., W } \\
v, \% \\
\end{array}$} \\
\hline & \multicolumn{3}{|c|}{ Modified wood / Modificirano drvo } & \multicolumn{3}{|c|}{ Non-modified wood / Nemodificirano drvo } \\
\hline & \multicolumn{6}{|c|}{ Working engagement $a_{e}, \mathrm{~mm} /$ Dodatak za obradu $a_{e}, \mathrm{~mm}$} \\
\hline & 0.5 & 1.0 & 2.0 & 0.5 & 1.0 & 2.0 \\
\hline 130 & $\begin{array}{c}33.94 \\
0.07 \\
1.14 \\
3.36\end{array}$ & $\begin{array}{c}60.97 \\
0.18 \\
2.86 \\
4.70\end{array}$ & $\begin{array}{c}95.71 \\
0.39 \\
6.44 \\
6.73\end{array}$ & $\begin{array}{c}35.97 \\
0.09 \\
1.36 \\
3.79\end{array}$ & $\begin{array}{c}63.15 \\
0.08 \\
1.33 \\
2.11\end{array}$ & $\begin{array}{c}96.73 \\
0.19 \\
3.04 \\
3.14\end{array}$ \\
\hline 160 & $\begin{array}{c}34.64 \\
0.10 \\
1.48 \\
4.26\end{array}$ & $\begin{array}{c}56.39 \\
0.10 \\
1.63 \\
2.89\end{array}$ & $\begin{array}{c}80.45 \\
0.33 \\
4.81 \\
5.98\end{array}$ & $\begin{array}{c}38.58 \\
0.06 \\
0.94 \\
2.44\end{array}$ & $\begin{array}{c}63.63 \\
0.25 \\
3.84 \\
6.03\end{array}$ & $\begin{array}{c}105.04 \\
0.32 \\
4.96 \\
4.72\end{array}$ \\
\hline 190 & $\begin{array}{c}32.40 \\
0.10 \\
1.47 \\
4.53\end{array}$ & $\begin{array}{c}50.78 \\
0.18 \\
2.91 \\
5.74\end{array}$ & $\begin{array}{c}69.56 \\
0.17 \\
2.68 \\
3.86\end{array}$ & $\begin{array}{c}38.85 \\
0.08 \\
1.33 \\
3.42\end{array}$ & $\begin{array}{c}63.48 \\
0.21 \\
3.29 \\
5.18\end{array}$ & $\begin{array}{c}93.04 \\
0.40 \\
6.43 \\
6.91\end{array}$ \\
\hline 220 & $\begin{array}{c}29.29 \\
0.12 \\
1.99 \\
6.79\end{array}$ & $\begin{array}{c}42.89 \\
0.10 \\
1.56 \\
3.65\end{array}$ & $\begin{array}{c}62.98 \\
0.16 \\
2.71 \\
4.31\end{array}$ & $\begin{array}{c}34.59 \\
0.08 \\
1.28 \\
3.70\end{array}$ & $\begin{array}{c}53.18 \\
0.11 \\
1.83 \\
3.44\end{array}$ & $\begin{array}{c}80.39 \\
0.33 \\
5.38 \\
6.66\end{array}$ \\
\hline
\end{tabular}

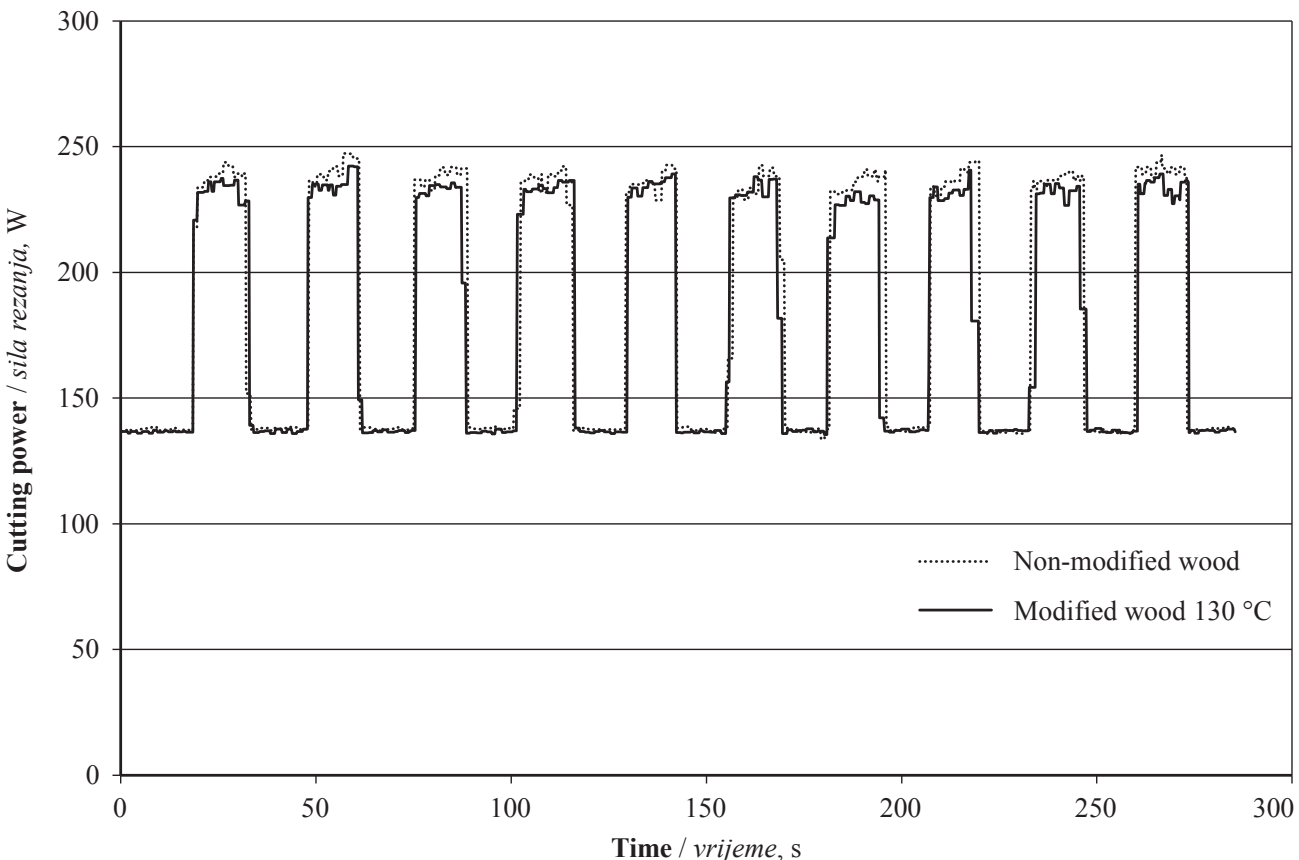

Figure 4 The course of measurements of cutting power for twin samples of non-modified wood and wood modified at $130{ }^{\circ} \mathrm{C}$ for the working engagement of $2 \mathrm{~mm}$

Slika 4. Rezultati mjerenja snage rezanja pri glodanju nemodificiranog drva i drva modificiranog pri temperaturi $130{ }^{\circ} \mathrm{C}$ uz dodatak za obradu visine $2 \mathrm{~mm}$

The cutting power also increases with an increase of the working engagement. This dependence confirms a relationship between these parameters, well-known in machining processes (Dmochowski, 1981; Rousek and Kopecký, 2005; Csanády and Magoss, 2011). The greater the working engagement, the greater the wood volume that has to be changed to chips, i.e. the greater machining work has to be performed in a unit of time, while maintaining the other machining parameters constant, such as e.g. feed rate, back engagement, rotational speed of the tool and the number of cutting blades.
With an increase in the working engagement, a greater increase in cutting power was recorded in the case of lower modification temperatures. Within the analysed range of the working engagement $(0.5-2.0$ $\mathrm{mm}$ ), the greatest increase in cutting power of modified wood was observed at $130{ }^{\circ} \mathrm{C}$, amounting to $180 \%$, while at $160{ }^{\circ} \mathrm{C}$, it was $130 \%$, with the smallest increase recorded at 190 and $220^{\circ} \mathrm{C}$, respectively, for which it amounted to $115 \%$.

Although in the case of thermally modified wood, an increase in the working engagement is accompanied 


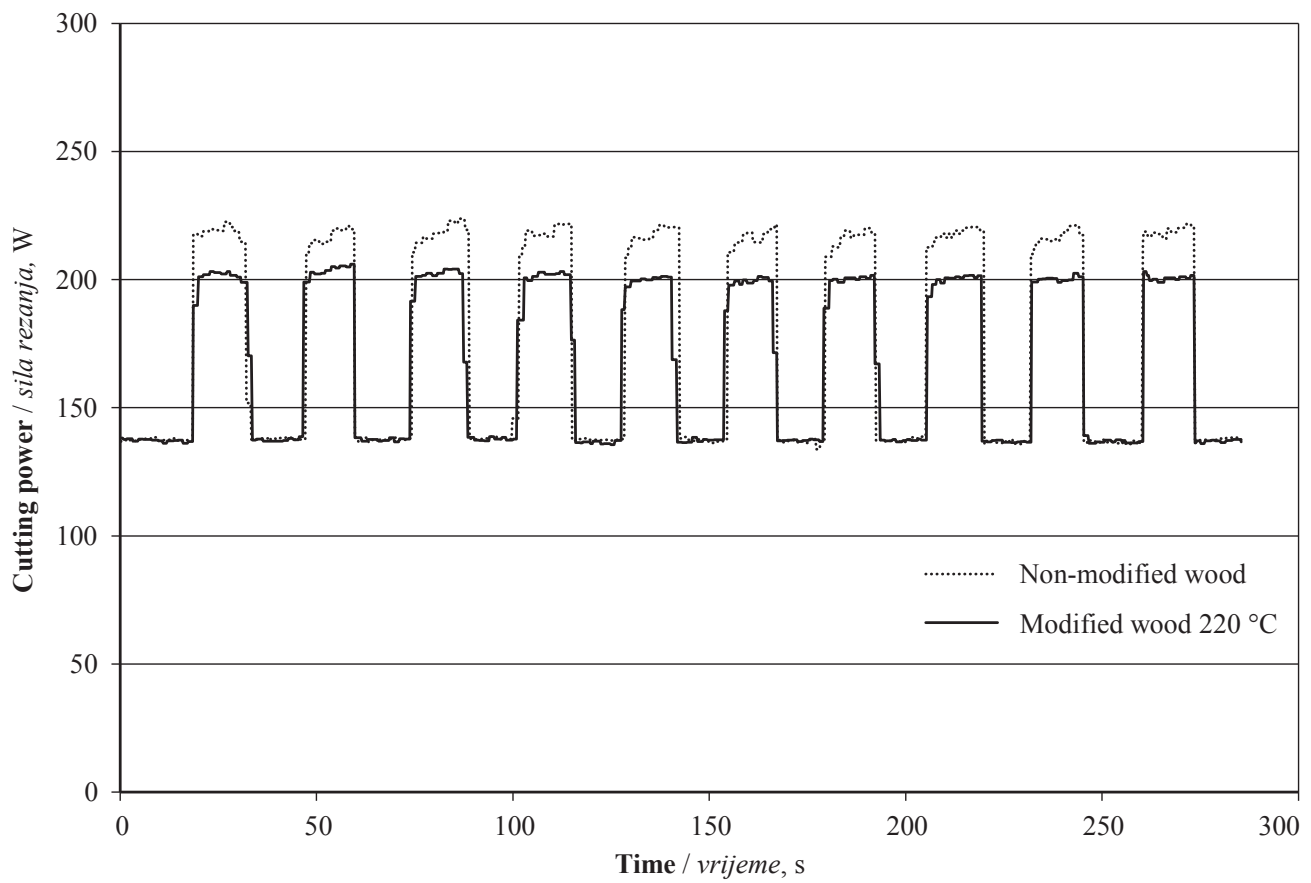

Figure 5 The course of measurements of cutting power for twin samples of non-modified wood and wood modified at $220^{\circ} \mathrm{C}$ for the working engagement of $2 \mathrm{~mm}$

Slika 5. Rezultati mjerenja snage rezanja pri glodanju nemodificiranog drva i drva modificiranog pri temperaturi $220^{\circ} \mathrm{C}$ uz dodatak za obradu visine $2 \mathrm{~mm}$

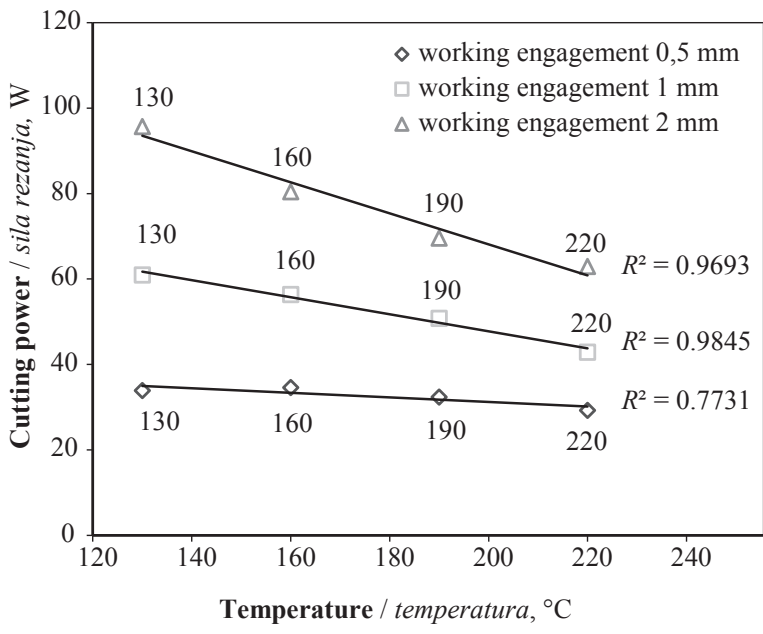

Figure 6 Cutting power of thermally modified wood depending on modification temperature

Slika 6. Snaga rezanja toplinski modificiranog drva u ovisnosti o temperaturi modifikacije

by an increase in cutting power, it decreases with an increase in modification temperature. In terms of the location of the cutting edge and the direction of the cutting motion in relation to the direction of the grain, lengthwise milling is lengthwise-transverse machining. In such a case, an increase in the working engagement causes an increase in the share of machining across the grain, i.e. an increase in cutting force and power. However, the reduced increase in cutting power in the case of thermally modified wood following an increase in the working engagement with the growing modification temperature indicates lower cutting forces, which may result from changes in cell wall ultrastructure and increased brittleness of thermally modified wood.
Reduction of cutting force as well as cutting power following an increase in the working engagement may result only from a decrease in mechanical strength properties of wood. Piernik (2014), in her analyses concerning the effect of thermal modification of wood on its mechanical properties, showed that the impact value of Scots pine wood modified at $220{ }^{\circ} \mathrm{C}$ is an equivalent of only $40 \%$ impact value of wood modified at $130{ }^{\circ} \mathrm{C}$. She also stated that an increase in modification temperature from 130 to $220{ }^{\circ} \mathrm{C}$ also causes a considerable reduction of Young's modulus in the radial direction by $27 \%$ and in the tangential direction by 46 $\%$. Results of numerous studies indicate changes in the structure of thermally modified wood, in turn leading to changes in its physical and mechanical properties. Depolymerisation of cellulose and a reduction of the degree of its crystallinity, as well as decreased contents of carbohydrate components in cell walls of wood were shown e.g. by Bhuiyan et al. (2000) and Yildiz and Gümüşkaya (2007). Also Hill (2006) and Doczekalska (2010), who investigating physico-mechanical properties of thermally modified wood and reported degradation of basic structural wood components, i.e. cellulose, lignin and hemicellulose, as well as degradation of extractives. Bekhta and Niemz (2003) and Pétrissans et al. (2003) showed that in the process of thermal modification, wood density decreases and in softwood resins and volatile substances are partly removed.

Values of cutting power at milling of twin samples of non-modified wood and wood thermally modified at different temperatures, depending on working engagement, are presented in Figs. 7a-d.

Cutting power of wood modified at $130{ }^{\circ} \mathrm{C}$ practically does not differ from that of non-modified 
a)
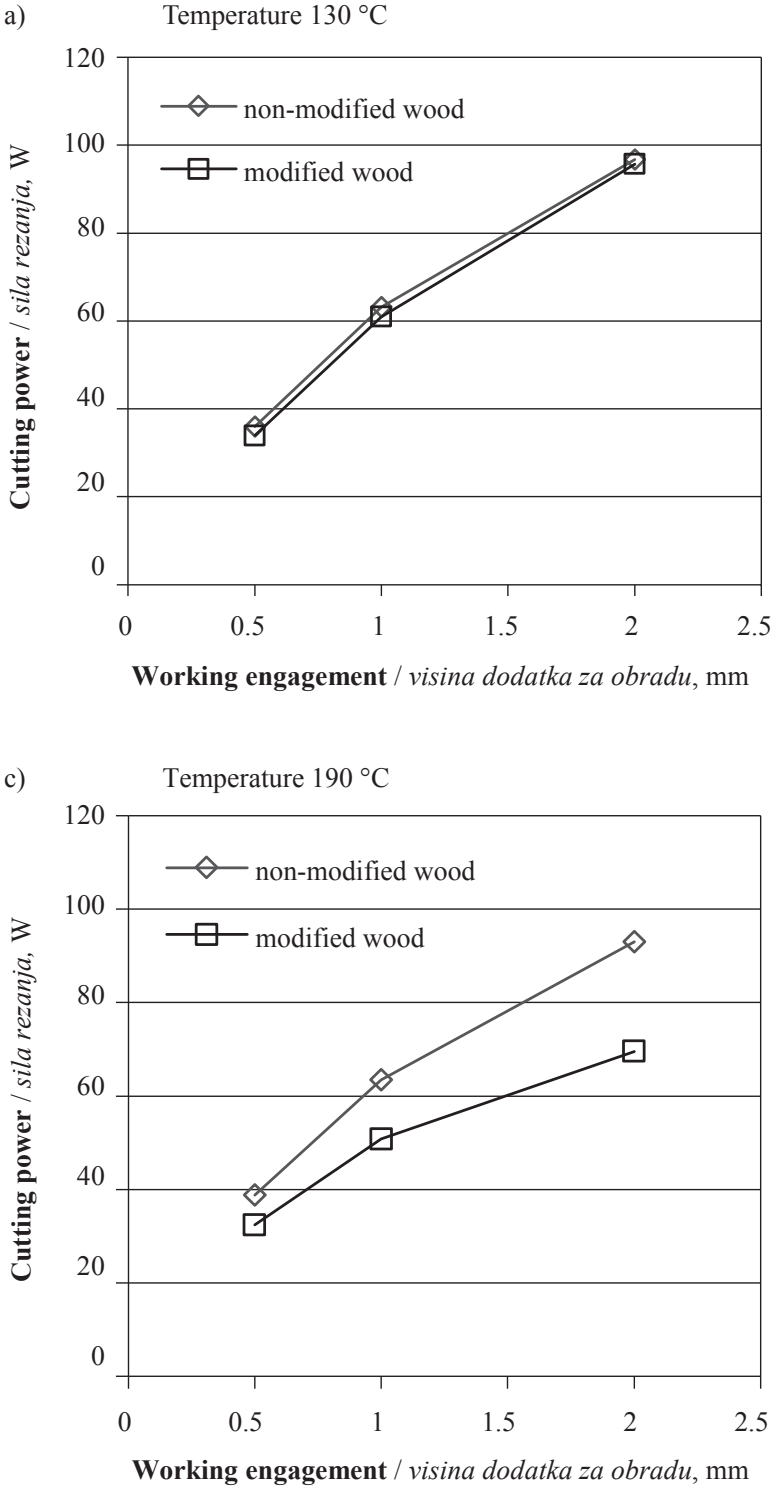

b)

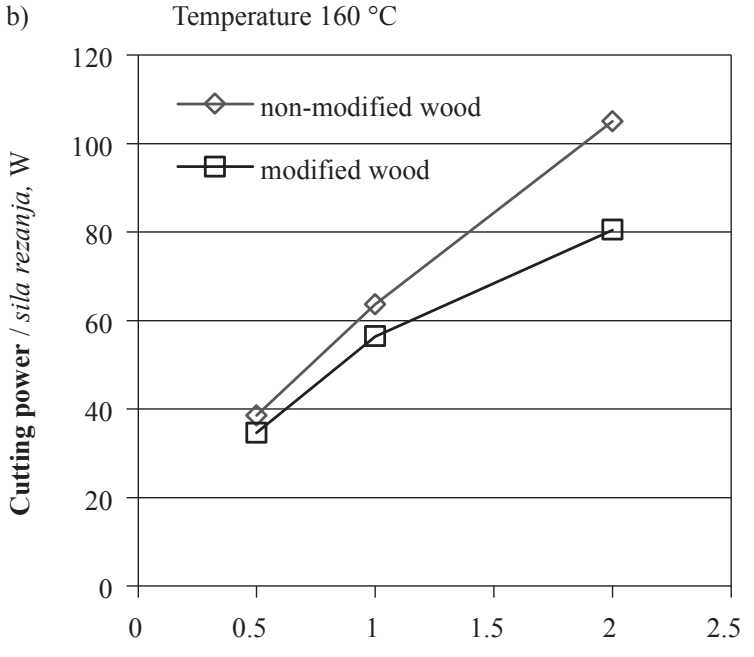

Working engagement / visina dodatka za obradu, mm

d)

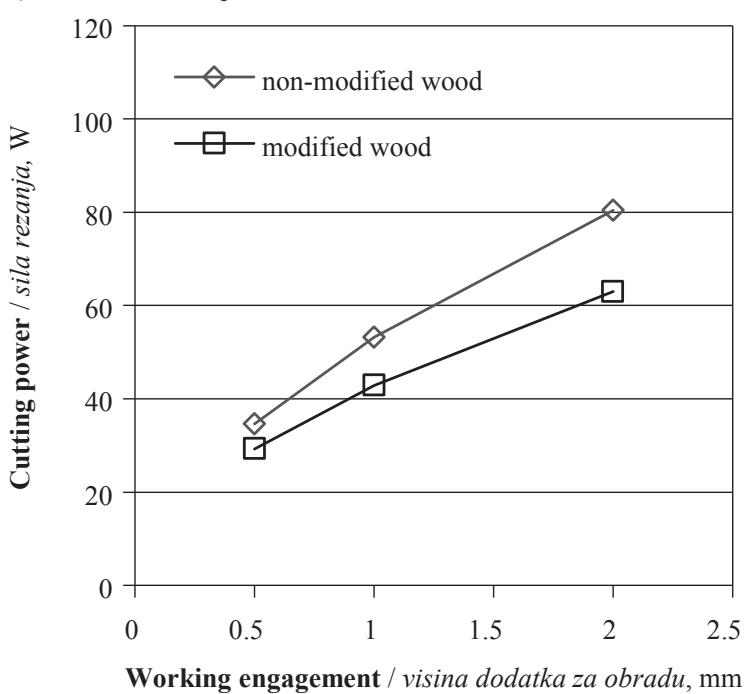

Figure 7 Cutting power of thermally modified and non-modified wood depending on working engagement for individual variants of modification temperature

Slika 7. Snaga rezanja toplinski modificiranoga i nemodificiranog drva u ovisnosti o visini dodatka za obradu za svaku varijantu temperature modifikacije drva

wood. At higher temperatures applied in the course of thermal treatment, a decrease in cutting power may be observed at milling of modified wood in comparison to non-modified wood. This reduction of energy requirement increases with the increase in the working engagement. For the working engagement of $0.5 \mathrm{~mm}$ and modification temperature of 160,190 and $220{ }^{\circ} \mathrm{C}$ it is a mean of $14 \%$, while it increases to $23 \%$ at the $2-\mathrm{mm}$ working engagement. For identical working engagement, in the case of wood thermally modified at different temperatures in comparison to non-modified wood, lower values of cutting power may be explained by changes in properties of modified wood. The mechanism of wood machining is an interaction between wood and the applied tool. It is determined by physical and mechanical properties of wood, geometry of the cutting edge and machining parameters. In the conducted experiment, the tool, its rotational speed and feed rate were constant factors. In contrast, the working engagement and the temperature of wood modification were variable parame- ters. The negative effect of modification on cutting power of wood starting at the temperature of $160{ }^{\circ} \mathrm{C}$ is consistent with our knowledge on the effect of modification on mechanical properties of wood. González-Peña and Hale (2007) and Boonstra (2008) stated that an increase in modification temperature above $150{ }^{\circ} \mathrm{C}$ results in reduction of tensile strength along the grain and bending strength, as well as an increase in hardness and fracture toughness. Causes for the variation in cutting power during milling in identical working engagement in non-modified and modified wood may thus be associated with changes in the ultrastructure of wood subjected to thermal treatment.

\section{CONCLUSIONS}

4 ZAKLJUČAK

Cutting power during milling of thermally modified wood:

- is lower than that of non-modified wood; the effect of thermal wood treatment on cutting power is manife- 
sted starting from the modification temperature of $160{ }^{\circ} \mathrm{C}$ and it increases with an increase in the working engagement,

- decreases with an increase in modification temperature,

- increases with an increase in the working engagement; the higher the temperature of wood modification, the lesser the increase in cutting power.

Mechanical and physical properties of thermally treated wood (especially higher brittleness), reduced cutting performance, because chips are easier to break and crumble.

\section{REFERENCE \\ 5. LITERATURA}

1. Ala-Viikari, J., 2007: The activities of Finnish Thermowood Association to commercialize ThermoWood®. In: The Third European Conference on Wood Modification, 15-16th October 2007, Cardiff, UK. (eds.) C. A. S. Hill, D. Jones, H. Militz \& G. A. Ormondroyd. Session 1: Commercial aspects: 3-10.

2. Barcík, S.; Gašparík, M., 2014: Effect of tool and milling parameters on the size distribution of splinters of planed native and thermally modified beech wood. BioResources, 9 (1): 1346-1360.

http://dx.doi.org/10.15376/biores.9.1.1346-1360

3. Bekhta, P.; Niemz, P., 2003: Effect of high temperature on the change in color, dimensional stability and mechanical properties of spruce wood. Holzforschung, 57: 539546. http://dx.doi.org/10.1515/HF.2003.080.

4. Bhuiyan, M. T. R.; Hirai, N.; Sobue, N., 2000: Changes of crystallinity of wood cellulose by heat treatment under dried and moisture conditions. Journal of Wood Science, 46 (6): 431-436. http://dx.doi.org/ 10.1007/BF00765800.

5. Boonstra, M. J.; Van Acker, J.; Tjeerdsma, B. F.; Kegel, E. F., 2007: Strength properties of thermally modified softwoods and its relation to polymeric structural wood constituents. Ann. For. Sci., 64: 679-690.

http://dx.doi.org/10.1051/forest:2007048.

6. Boonstra, M. J., 2008: A two-stage thermal modification of wood. Ph.D. dissertation in co-supervision Ghent University and Université Henry Poincaré - Nancy 1, pp. 297.

7. Borysiuk, P.; Mamiński, M., 2007: Modyfikacja drewna - stan obecny i perspektywy rozwoju. [Wood modification - the present status and prospects for the future]. Biuletyn Informacyjny Ośrodka Badawczo-Rozwojowego Przemysłu Płyt Drewnopochodnych w Czarnej Wodzie, 47 (3-4): 150-161.

8. Csanády, E.; Magoss, E., 2011: Mechanics of wood machining. Printed by Lővér-print Nyomdaipari KFT. Department of Wood Engineering, University of West Hungary, Sopron, pp.243.

9. Dmochowski, J., 1981: Podstawy obróbki skrawaniem. [Foundations of machining]. Państwowe Wydawnictwo Naukowe. Warszawa; pp.586.

10. Doczekalska, B., 2010: Badania nad modyfikacją drewna w aspekcie jego wykorzystania jako napełniacza polipropylenu. [Investigations on wood modification from the point of view of its utilization as polypropylene filler]. Rozprawy naukowe 416. Wydawnictwo Uniwersytetu Przyrodniczego w Poznaniu, pp.110

11. Dzurenda, L.; Orłowski, K. A., 2011: The effect of thermal modification of ash wood on granularity and homogeneity of sawdust in the sawing process on a sash gang saw PRW 15-M in view of its technological usefulness. Drewno: prace naukowe, doniesienia, komunikaty, 54 (186): 27-37.
12. Dzurenda, L.; Orłowski, K. A.; Grzeskiewicz, M., 2010: Effect of Thermal Modification of Oak Wood on Sawdust Granularity. Drvna industrija, 61 (2): 89-94.

13. Fengel, D.; Wegener, G., 1984: Wood. Chemistry, ultrastructure, reactions. Berlin. New York: 258-271.

14. González-Peña, M. M.; Hale, M. D. C., 2007: The relationship between mechanical performance and chemical changes in thermally modified wood. In: The Third European Conference on Wood Modification, 15-16th October 2007, Cardiff, UK. (eds.) C. A. S. Hill, D. Jones, H. Militz \& G. A. Ormondroyd. Session 4: Poster session 1: 169-172.

15. Hill, C., 2006: Wood modification: Chemical, thermal and other processes. John Wiley \& Sons Press.; pp. 260. http://dx.doi.org/10.1002/0470021748

16. Jämsä, S.; Ahola, P.; Viitaniemi, P., 2000: Long-term natural weathering of coated ThermoWood. Pigment and Resin Technology, 29 (2): 68-74. http://dx.doi.org/10.1108/03699420010317807.

17. Nakao, T.; Okano, T.; Asano, I., 1983: Effects of heat treatment on the loss tangent of wood. Mokuzai Gakkaishi, 29 (10): 657-662.

18. Orłowski, K. A.; Grześkiewicz, M., 2009: The effect of heat treatment of hardwood on the specific cutting resistance. Ann. WULS - SGGW, For. and Wood Technol., 69:147-157.

19. Orłowski, K. A., Wierzbowski, M. A., 2010: Fracture toughness and shear yield strength determination of steam kiln-dried wood. In: "The Future of Quality Control for Wood \& Wood Products', 4-7th May 2010, Edinburgh The Final Conference of COST Action E53" (http:// www.coste53.net/downloads/Edinburgh/Edinburgh-Presentation/18.pdf).

20. Pétrissans, M.; Géradin, P.; El-Bakali, I.; Seraj, M., 2003: Wettability of heat-treated wood. Holzforschung, 57: 301-307. http://dx.doi.org/ 10.1515/HF.2003.045.

21. Piernik, M., 2014: Badania wpływu termicznej modyfikacji drewna sosny (Pinus sylvestris L.) na zmiany barwy oraz wybranych właściwości mechanicznych. [Studies on the effect of thermal modification of Scots Pine wood (Pinus sylvestris L.) on changes in colour and selected mechanical properties]. Ph.D. dissertation prepared at the Department of Woodworking Machinery and Basis of Machines Construction, the Poznań University of Life Sciences; pp.163.

22. Rousek, M.; Kopecký, Z., 2005: Monitoring of power consumption in high-speed milling. Drvna industrija, 56 (3): 121-126.

23. Yildiz, S.; Gümüşkaya, E., 2007: The effects of thermal modification on crystalline structure of cellulose in soft and hardwood. Building and Environment, 42: 62-67. http://dx.doi.org/10.1016/j.buildenv.2005.07.009.

24. *** 2003: ThermoWood ${ }^{\circledR} H a n d b o o k$. Finnish Thermowood Association, Helsinki; pp.66.

\section{Corresponding address:}

Assoc. prof. ANDRZEJ KRAUSS, Ph.D.

Poznań University of Live Sciences

Faculty of Wood Technology

Department of Woodworking Machinery

and Basics of Machine Design

Wojska Polskiego 28

60-637 Poznań, POLAND

e-mail: akrauss@up.poznan.pl 